\title{
Groundwater quality assessment using geoelectrical and geochemical approaches: case study of Abi area, southeastern Nigeria
}

\author{
Ebong D. Ebong ${ }^{1} \cdot$ Anthony E. Akpan $^{1} \cdot$ Chimezie N. Emeka $^{2} \cdot$ Job G. Urang $^{1}$
}

Received: 24 April 2015/ Accepted: 6 June 2016/Published online: 18 June 2016

(c) The Author(s) 2016. This article is published with open access at Springerlink.com

\begin{abstract}
The electrical resistivity technique which involved the Schlumberger depth sounding method and geochemical analyses of water samples collected from boreholes was used to investigate the suitability of groundwater aquifers in Abi for drinking and irrigation purposes. Fifty randomly located electrical resistivity data were collected, modeled, and interpreted after calibration with lithologic logs. Ten borehole water samples were collected and analysed to determine anion, cation concentrations and some physical and chemical parameters, such as water colour, temperature, total dissolved solids, and electrical conductivity. The results show that the lithostratigraphy of the study area is composed of sands, sandstones (fractured, consolidated and loosed), siltstones, shales (compacted and fractured) of the Asu River Group, Eze-Aku Formation which comprises the aquifer units, and the Nkporo Shale Formation. The aquifer conduits are known to be rich in silicate minerals, and the groundwater samples in some locations show a significant amount of $\mathrm{Ca}^{2+}, \mathrm{Mg}^{2+}$, and $\mathrm{Na}^{+}$. These cations balanced the consumption of $\mathrm{H}^{+}$during the hydrolytic alteration of silicate minerals. The geochemical analysis of groundwater samples revealed dominant calcium-magnesium-carbonatebicarbonate water facies. Irrigation water quality parameters, such as sodium absorption ratio, percentage of sodium, and permeability index, were calculated based on the physico-chemical analyses. The groundwater quality
\end{abstract}

Ebong D. Ebong

dickebong@yahoo.co.uk; ebongdickson@unical.edu.ng

1 Applied Geophysics Programme, University of Calabar, PMB 1115, Calabar, Cross River State, Nigeria

2 Department of Geology, University of Calabar, PMB 1115, Calabar, Cross River State, Nigeria was observed to be influenced by the interaction of some geologic processes but was classified to be good to excellent, indicating its suitability for domestic and irrigation purposes.

Keywords Electrical sounding · SAR · Permeability index · Water facies · Physico-chemical

\section{Introduction}

Groundwater is the most preferred and effective source of water for agricultural and domestic uses. Groundwater supply has increased significantly in recent times and becomes the main water source for all purpose in rural and urban areas of West Africa, especially in the dry season (Pimentel et al. 1997). The surface water resources in this region, influenced by seasonal rainfall include rivers, lakes, and dams (Pimentel et al. 1997). The increasing water need is acknowledged for Abi area during the last few decades due to the establishment of both micro- and macro-agricultural development projects, such as the Abi Songhai Farm Limited. More than $75 \%$ of water used in agricultural projects of such magnitude will be derived from freshwater resources available in close area (Wallace 2000). Given that the use of contaminated surface water for domestic purposes engenders several endemic health problems resulting from water-borne diseases (e.g., guinea worm, cholera, dysentery); we have undertaken this study to contribute to the investigation for additional good quality water resources. Most of the water sources used by the rural people are rivers, streams, ponds, and lakes, which are highly vulnerable due to surface contaminants resulting from anthropogenic activities (Akpan et al. 2013). Several donor agencies (e.g., United Nations Children Emergency 
Fund, European Union, Micro Project Programme in the nine Niger Delta States, Niger Delta Development Commission, and Cross River State Community and Social Development Agency) in partnership with the government of Cross River State have been involved in several capacities to ameliorate the impending water supply challenges of the people. These agencies have made concerted efforts, geared towards tackling these problems by funding to drilling of water boreholes in communities, and provision of other social amenities to alleviate the sufferings of the people. The suitability of groundwater resources for the afore-mentioned purposes is of immense importance and, therefore, requires routine assessment to determine its quality (Ketata et al. 2011).

Hydrogeophysical researches within the Ikom Mamfe Embayment (IME) (Fig. 1) revealed that the groundwater resource is not evenly distributed. While some areas have huge quantities of this resource, others are limited due to the complex geologic history of the area (Ebong et al. 2014; Akpan et al. 2013). Over time, the embayment has been under serious threats resulting from failure of water boreholes, rapid depletion of groundwater in most part of the area as a result of excessive abstraction, and contaminants from geologic formations, soils, and sediments (Papadopoulou-Vrynioti et al. 2013, 2014), and anthropogenic sources (Akpan et al. 2015). Population growth together with the development of agricultural and industrial activities in the study area resulted in an increasing demand for water. However, studies of groundwater quality within the Mamfe area are roughly regional and seem not to be relevant for local scales. It is why our investigation comes to assess the suitability of the aquifer system within Abi area for both domestic and irrigation purposes. Within this investigation, we used the depth sounding method together with geochemical and hydrogeologic data. The depth sounding method has been successfully applied in solving a wide range of hydrological, hydrogeophysical, engineering, and environmental problems, including aquifer mapping and geohydraulic parameter estimation (Soupios et al. 2007; Massoud et al. 2010; Ebong et al. 2014), characterisation of aquifer formation, assessment of infiltration rate of the vadose zone, and groundwater contamination studies (Inoubli et al. 2006; Samsudin et al. 2007; Ogilvy et al. 2008; Gemail et al. 2011; Minsley et al. 2011; Akpan et al. 2013; Mhamdi et al. 2015). Multi-criteria spatial geochemical data analyses have been used by several authors to determine contaminant levels from groundwater samples (Bathrellos et al. 2008; Panagopoulos et al. 2012). The main objective of this investigation in Abi, southeastern Nigeria is to assess the quality, availability, and distribution of groundwater resources, for domestic and agricultural uses.

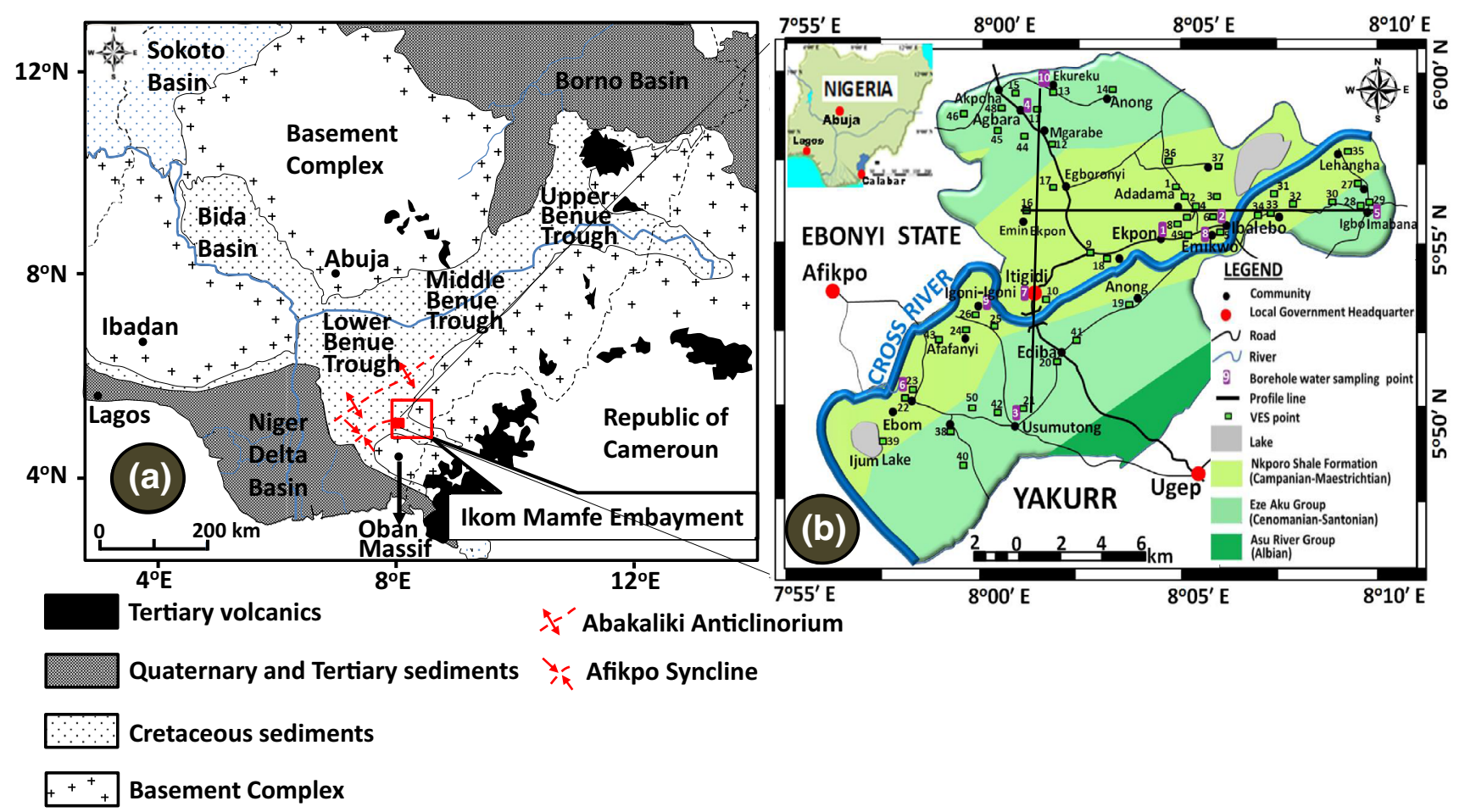

Fig. 1 a Geologic map of Nigeria showing the Lower Benue Trough, the Ikom Mamfe Embayment, and Abi area (red box), and b geologic map of Abi showing vertical electrical sounding (VES) points, borehole water sample points, E-W and N-S pseudo-resistivity profile lines 


\section{Geological setting}

Abi area is located between longitudes $7.93^{\circ}$ and $8.17^{\circ} \mathrm{E}$ and latitudes $5.76^{\circ}$ and $6.02^{\circ} \mathrm{N}$ in Cross River State, Nigeria (Fig. 1b). The area is limited by Ebonyi State to the north; it is adjacent to Yakurr and Obubra to the northeast and limited to the south by Biase. Abi is located in the IME which extends between longitudes $7.75^{\circ}$ and $8.75^{\circ} \mathrm{E}$ and latitudes $5.25^{\circ}$ and $6.50^{\circ} \mathrm{N}$ (Akpan et al. 2013). Studies by Petters et al. (1987) showed that the IME is the NW-SE splay segment of the NE-SW trending Benue Trough and always referred to as a contiguous part of the Lower Benue Trough (LBT). The IME segment of the LBT extends laterally into parts of western Cameroun, where it covers an area of $2016 \mathrm{~km}^{2}$ (Nguimbous-Kouoh et al. 2012). The IME is bounded to the northeast by the Obudu Plateau and the Cameroun Volcanic Line and to the west by the Abakaliki Anticlinorium and Afikpo Syncline. In the southeastern part, it is bounded by the Oban Massif in Cross River State, Nigeria (Fig. 1a). The IME is characterised by low relief and gently undulating topography (Eseme et al. 2002) and cuts across Abi, Obubra, Yakurr, Biase, and Ikom local government areas (LGAs) in Cross River State. Following the mid-Santonian tectonism and magmatism, the depositional axis in the Benue Trough was displaced westward resulting in subsidence of the Anambra Basin. The Anambra basin, which is part of the LBT, contains sediments of CampanianMaestrichtian to Eocene ages which are not present in the IME (Odigi 2011) (Fig. 2).
Tectonically, the IME is believed to have its origin traceable to the regional tectonic episode that resulted to the splitting of the African and South American Continents. The Benue Trough was formed due to the failed rift (aulacogen) of the triple junction rift system and was, subsequently, filled with sediments (Murat 1972). Compressional folding during the mid-Santonian affected the entire Benue Trough producing several structures, such as the Abakaliki Anticlinorium and Afikpo Syncline, which later became Afikpo Basin (Benkhelil 1982).

Sedimentation in the IME began with the deposition of marine Albian Asu River Group (ARG), which is the first lithostratigraphic unit resting unconformably on the Precambrian crystalline basement (PCB). The PCB consists basically of migmatitic gneiss, granitic gneiss, and schist with some pegmatitic intrusions in some locations (Fig. 1a). The gneisses within the PCB are usually foliated with some pink feldspathic materials and vary from black to white hornblende, with porphyroclastic feldspars (Akpan et al. 2013; Ekwueme et al. 1995). The regional strike direction of these rocks is $\mathrm{N}-\mathrm{S}$, although some occasional NE-SW swings have also been reported by Odoh (2010) and Ekwueme (2003). Some pyroclastics of Aptian-Early Albian ages have been sparingly reported (Odigi and Amajor 2009). The ARG, nonmarine-to-marginal marine character sediments, consists of impermeable shales, sand lenses, sandstone intercalations, and ammonite-rich limestones (Petters et al. 1987).

The late Albian-Cenomanian thick flaggy impermeable calcareous and non-calcareous black shale; siltstone and
Fig. 2 Stratigraphic chart of the Ikom Mamfe Embayment and adjoining Anambra and Afikpo Basins

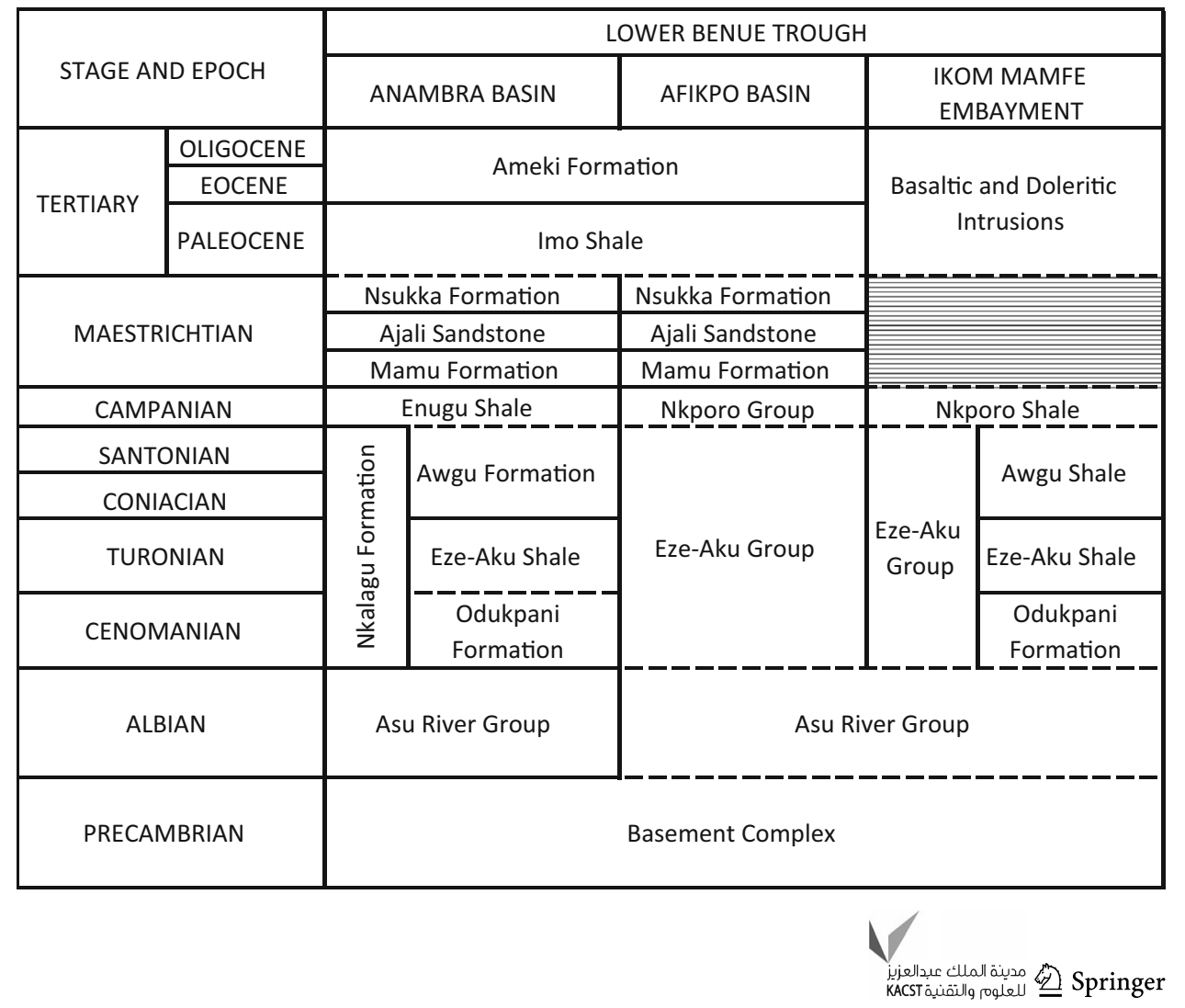


sandstone of the Eze-Aku Group (EAG), which correlates with the marine Cenomanian-Turonian Nkalagu Formation (black shale, limestone and siltstone) and the interfingering regressive sandstones of the Agala Formation, overlays the ARG. The thickness of this formation do exceed $100 \mathrm{~m}$ locally (Ukaegbu and Akpabio 2009). Murat (1972) reported that the Eze-Aku Shale reflects deposits of marine condition in a tectonically controlled basin and the sandstone deposits marked a period of regression, while the shale deposits indicate a period of transgression. These Cretaceous sediments are occasionally intruded by dense, fine-grained, and sometimes dark coloured Tertiary volcanic rocks, such as basalts and dolerites in some locations (Benkhelil 1982). The post-Cretaceous tectonic activities, which were believed to have originated from the adjoining Cameroun Volcanic Province and other low-grade metamorphism in the area, caused serious fracturing of the basement rocks and deformation of the adjoining Cretaceous lithostratigraphic units (Ebong et al. 2014; Akpan et al. 2013). Thus, the overlying Cretaceous sequence is highly baked, domed, and seriously deformed in many locations (Etuk et al. 2008; Offodile 1975). In many locations, the sandstones in the EAG form ridges that averagely strike at $\mathrm{N} 40^{\circ} \mathrm{E}$ and dip between $20^{\circ}$ and $68^{\circ}$, e.g., Owutu-Afikpo-Adadama Ridge system (OAASRS) (Odigi and Amajor 2009). The shales within the EAG was reported by Okereke et al. (1998), as having secondary properties, such as interconnected porosities, joints, fractures, and folds, resulting from syn- and post-depositional deformations. These properties are very significant and necessary in the transmission and storage of fluid (Raju and Reddy 1998). These striking characteristics of the IME introduce a slight geologic complexity in the lithostratigraphic architecture of the area at certain locations, especially those localities around the geologic contacts. The Nkporo Shale Formation (NSF) that Petters (1989) and other authors refer to as the Nkporo-Afikpo Shale Province unconformably overlay the Post-Santonian hiatus and represent a fossiliferous pro-deltaic facies of the late Campanian-early Maestrichtian brackish marsh deposits consisting of shale and sandstone lenses (Odigi 2011). Deposition of the sediments of the NSF reflects a funnelshaped shallow marine setting that graded into channel low-energy marshes which roughly runs across the Benue Trough (Odigi 2011).

\section{Hydrogeology}

Groundwater conditions in aquifers are influenced by the intensity of precipitation, amount of water and duration, depth of weathering, specific yield, and slope of formation towards drainage channels (Srinivasamoorthy et al. 2014).
It can occur in a confined or an unconfined state. The shallow aquifers $(\sim 60 \mathrm{~m})$ within the area are products of high-level metamorphism and fracturing of the EAG. Hence, the fractured shales and sandstones, sand lenses, and siltstones are the main groundwater aquifers in the area (Ebong et al. 2014). Permeability values vary from 2.0 to $3.0 \mathrm{~m} /$ day around the fractured shale and siltstone aquifers. The sandstone and fractured sandstone aquifers show permeability, which range between 3.2 and $4.5 \mathrm{~m} /$ day. Aquifer thicknesses vary between 7 and $27 \mathrm{~m}$, while transmissivity ranges between 25 and $100 \mathrm{~m}^{2} /$ day (Ebong et al. 2014). However, research in the area suggests that some high yielding aquifers exist at depths greater than $100 \mathrm{~m}$. These aquifer structures are highly localized (Akpan et al. 2013, 2015).

Average annual precipitation and average relative humidity for the area are over $2200 \mathrm{~mm}$ and about $88 \%$, respectively (Akpan et al. 2013), while annual temperature is between 23 and $27{ }^{\circ} \mathrm{C}$ in the rainy season and rises to a peak value of $35^{\circ} \mathrm{C}$ in the dry season (Ebong et al. 2014). The main drain in the study area is the Cross River, which experiences variations in water volume with seasons. Other smaller water inlets, such as rivers and streams, which serve as tributaries to the main drain (Cross River), also drain the area. At the peak of the rainy season, water levels in both the groundwater and surface water resources attain maximum heights, while the major drain overflows its banks. Topographic-induced water flow influences the flow of seepages from the OAASRS towards the low-lying areas, resulting in saturated soils within these areas in the rainy season (Ebong et al. 2014). Towards the end of the dry season, the volume of water in the rivers and streams decreases due to loss of water to local surface waters, such as ponds, localized evapotranspiration, and predominantly, the main drain (Cross River). During this period, water flow within the Cross River is restricted to narrow channels within the river bed.

\section{Materials and methods}

\section{Geoelectrical data acquisition and analyses}

The geoelectrical resistivity technique, involving vertical electrical sounding (VES) surveys, was performed using the Schlumberger electrode configuration. This procedure is known to generate reliable shallow subsurface stratigraphic contrasts. This technique uses two pairs of electrodes technically referred to as the current and potential electrodes connected to a resistivity meter. The resistivity meter used during the investigation was the IGIS resistivity meter (model SSR-MP-ATS). Fifty (50) evenly distributed depth soundings were completed in the area (Fig. 2), and 
some were close to borehole locations which enable the correlation of the sounding data with lithologic logs from the boreholes. The current electrode spacing ranges from a minimum of $2 \mathrm{~m}$ to a maximum of $800 \mathrm{~m}$, while the potential electrode spacing varies between 0.25 and $20 \mathrm{~m}$. These values were chosen to enable optimal mapping of both shallow and deeply seated structures (>100 m), assuming that penetration is about $1 / 6$ of maximum current electrode spacing. Potential electrode values at cross-over points were carefully selected to take on integer multiples of their previous values, so that observed resistances can be visually converted and compared with previous value at the same current electrode position. Observed data were plotted manually in the field on a bi-logarithmic graph by plotting half-current electrode spacing on the abscissa against apparent resistivity $\left(\rho_{\mathrm{a}}\right)$ on the ordinate axes, respectively. This exercise was done for each sampling point to assess the quality of data acquired before moving to the next survey point. Standard curve matching and smoothening techniques were also adopted where necessary, and qualitative interpretations carried out using standard charts (Orellana and Moony 1966). The RESIST code developed by Vender Velpen (1988) was employed in the computer-aided modeling process. The input parameters (e.g., resistivities and depths) used as starting models during the inversion process were derived from manually interpreted curves and were constrained using lithologic logs. The lithologic logs used were those from boreholes closest to the VES points acquired from the Cross River State Rural Water Supply and Sanitation Agency (CRSRUWATSSA) and the Cross River State Community and Rural Development Agency (CRSCRDA). The RESIST software compared the field data with the synthetic models and displayed their differences using the root-mean-square (RMS) technique. High RMS errors were prevalent in noisy data sets, which were traced to poor electrode-ground contacts. Such noisy raw data were either smoothened manually or removed by applying user-defined filtering criteria built into the software. Iterative procedure was performed to reduce the high RMS values to a user-defined confidence level of $5 \%$. Beyond this level, the initial input parameters were adjusted, and the iteration procedure was repeated. Constraints on the depth obtained from the inversion process were provided by comparing observed depths with lithologic data. The inversion process after a couple of iterations provided models that best fit the curves in a least square sense (Inman 1975).

\section{Groundwater sampling and analyses}

Water samples meant for hydrochemical analyses were collected from ten sampling points using two polyethylene bottles thoroughly rinsed with distilled water. A preservative - concentrated nitric acid-was put inside one of the two sample bottles. The nitric acid, when dissolved in water, lowers its $\mathrm{pH}$, and thus prevents precipitation of cations when in transit. The sample bottles were once again rinsed at least three times using groundwater collected from the sampled borehole water. The samples were collected, labeled, sealed, and stored following APHA (1995) standards in all cases. All the water samples were collected after the water from the borehole has been pumped for at least 10 min (Ketata et al. 2011). The HI98130 model of Combo electrical conductivity (EC) and $\mathrm{pH}$ meter from Hanna Instruments, USA, was used for in situ measurement of physico-chemical parameters (EC, pH, TDS and temperature), because these parameters vary with atmospheric condition, such as temperature. Geographic coordinates of the water sampling and VES locations, used in posting borehole and VES points on Abi map, were measured using GPSMap 76C model of a global position system (Fig. 1b). The flame photometer was used in measuring the concentrations of $\mathrm{Na}^{+}$and $\mathrm{K}^{+}$, while volumetric method was used in the analyses of total hardness $\left(\mathrm{CaCO}_{3}\right)$, calcium $\left(\mathrm{Ca}^{2+}\right)$, carbonate $\left(\mathrm{CO}_{3}{ }^{2-}\right)$, bicarbonate $\left(\mathrm{HCO}_{3}{ }^{-}\right)$, and chloride $\left(\mathrm{Cl}^{-}\right) \cdot \mathrm{Mg}^{2+}$ was calculated from concentrations of total hardness and calcium (Eq. 1) according to Sawyer et al. (2003) as:

Total Hardness $(\mathrm{mg} / \mathrm{l})=\left(\mathrm{Ca}^{2+}+\mathrm{Mg}^{2+}\right) \times 50$

where $\mathrm{Ca}^{2+}$ and $\mathrm{Mg}^{2+}$ concentrations are expressed in meq/l. Sulphates $\left(\mathrm{SO}_{4}{ }^{3-}\right)$ were measured using the colorimetric technique. The samples meant for heavy metal analyses were acidified to a $\mathrm{pH}$ of 2 using nitric acid. Richards (1954)'s equation was used to calculate the Sodium Adsorption Ratio (SAR) necessary in ascertaining the suitability of groundwater for irrigation purposes

$\mathrm{SAR}=\frac{\mathrm{Na}^{+}}{\sqrt{\frac{\mathrm{Ca}^{2+}+\mathrm{Mg}^{2+}}{2}}}$.

Sodium percent ( $\mathrm{Na} \%)$ was used to assess the amount of sodium in irrigation water (Prasanth et al. 2012). It is a parameter commonly used in expressing the fitness of water for irrigation purposes, because reaction of sodium with soils reduces permeability. Excess amount of sodium in irrigation water, which can cause changes in soil properties, was calculated using Todd and Mays (2005) equation:

$\mathrm{Na} \%=\frac{\left(\mathrm{Na}^{+}+\mathrm{K}^{+}\right) \times 100}{\left(\mathrm{Ca}^{2+}+\mathrm{Mg}^{2+}+\mathrm{Na}^{+}+\mathrm{K}^{+}\right)}$.

The permeability index (PI) is another parameter for rating the suitability of water for irrigation purposes. Soil permeability is affected by the long-term use of irrigation water, as it is influenced by its $\mathrm{Na}^{+}, \mathrm{Ca}^{2+}, \mathrm{Mg}^{2+}$, and 
$\mathrm{HCO}_{3}{ }^{-}$composition. PI, as defined by Ragunath (1987), was computed using the following:

$\mathrm{PI}=\frac{\mathrm{Na}^{+}+\sqrt{\mathrm{HCO}_{3}^{-}}}{\mathrm{Ca}^{2+}+\mathrm{Mg}^{2+}+\mathrm{Na}^{+}+\mathrm{K}^{+}} \times 100$.

The WAGTECH spectrophotometer method was employed to measure the concentrations of some anions: nitrite $\left(\mathrm{NO}_{2}{ }^{-}\right)$, nitrate $\left(\mathrm{NO}_{3}{ }^{-}\right)$, phosphate $\left(\mathrm{PO}_{4}{ }^{3-}\right)$, sulphate $\left(\mathrm{SO}_{4}{ }^{2-}\right)$, and cations: total iron $(\mathrm{Fe})$, zinc $(\mathrm{Zn})$, and manganese $(\mathrm{Mn})$. All the water samples were analysed following standard procedures prescribed by APHA (1995) in the CRS-RUWATSSA Laboratory, Calabar. Observed concentrations were compared with the World Health Organization, WHO (2010) standards for potable water. Routine analyses of blanks, duplicates, and ionic balance checks were performed during sample analyses. To meet the electroneutrality requirement, cation-anion balance error was calculated and was observed to be within $\pm 5 \%$.

\section{Results and discussion}

\section{Geoelectrical interpretation}

Subsurface models generated from the VES data with constraints from lithologic logs were used to construct electrostratigraphic units. Figure 3 shows samples of the modeled curves generated in the area. These one-dimensional (1-D) models were used to construct the electrostratigraphic section, which reveals the subsurface stratigraphic distribution in east-west direction. The section correlated well with lithologic description from borehole logs (Fig. 4). All the 1-D inverted resistivity curves, lithologic logs, and the distances between adjacent resistivity sounding points used for the construction of the electrostratigraphic units were assumed to lie on the same geometric plane. Based on the regional geology of the area, three main sedimentary formations comprising ARG, EAG, and NSG were identified. The epithelial electrostratigraphic unit is dominated by fine-textured argillaceous sediments and some arenaceous materials with resistivity values $\leq 200 \Omega \mathrm{m}$. These relatively low-resistivity sediments cap the entire area from east to west. These relatively low-resistivity sediments are directly underlain by a thin (3-7 m) unit with slightly higher resistivities that conform to sandstone ( $>500 \Omega \mathrm{m}$ ) materials in the lithologic section. The lithologic log from Ekpon area captures the vertical and lateral continuities of the unit across the profile. This sandstone unit is continuous with the Late Turonian-Coniacian calcareous Amaseri Sandstone ridge, and it grades into a shaly formation (Odigi and Amajor 2009) in most parts of the study area. This thin (3.9-5.7 m) sandstone unit, characterised by higher resistivities $(\geq 200 \Omega \mathrm{m})$, is underlain by an imbricate sand-shale unit around Emin Ekpon and Adadama areas before grading into clay in areas around Ilike and Mboti. A sandstone pinch out, inferred to be part of the Turonian-Coniacian sandstone ridge, was identified at depths of $\sim 25 \mathrm{~m}$,
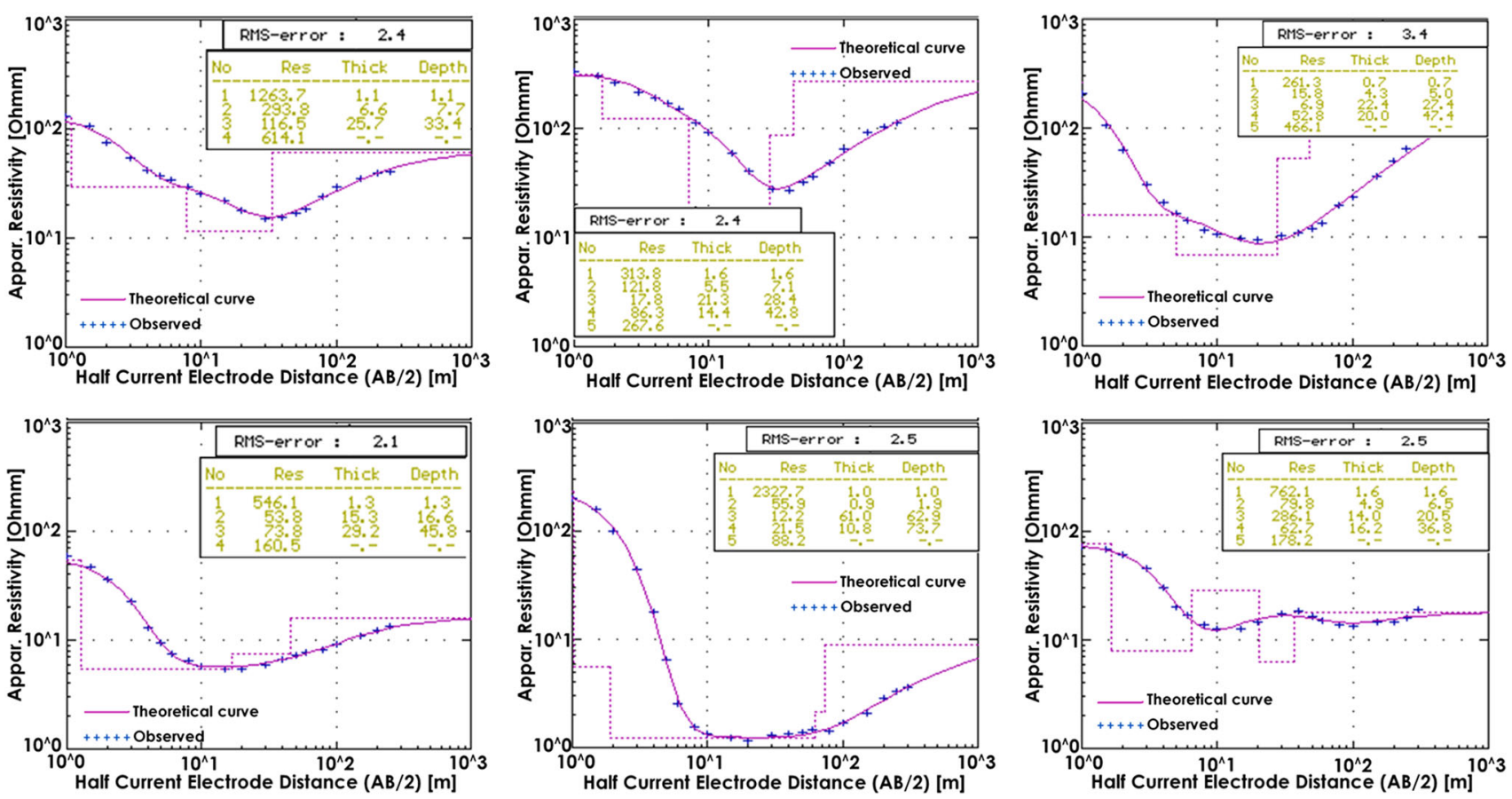

Fig. 3 Sampled 1-D inverted resistivity models 


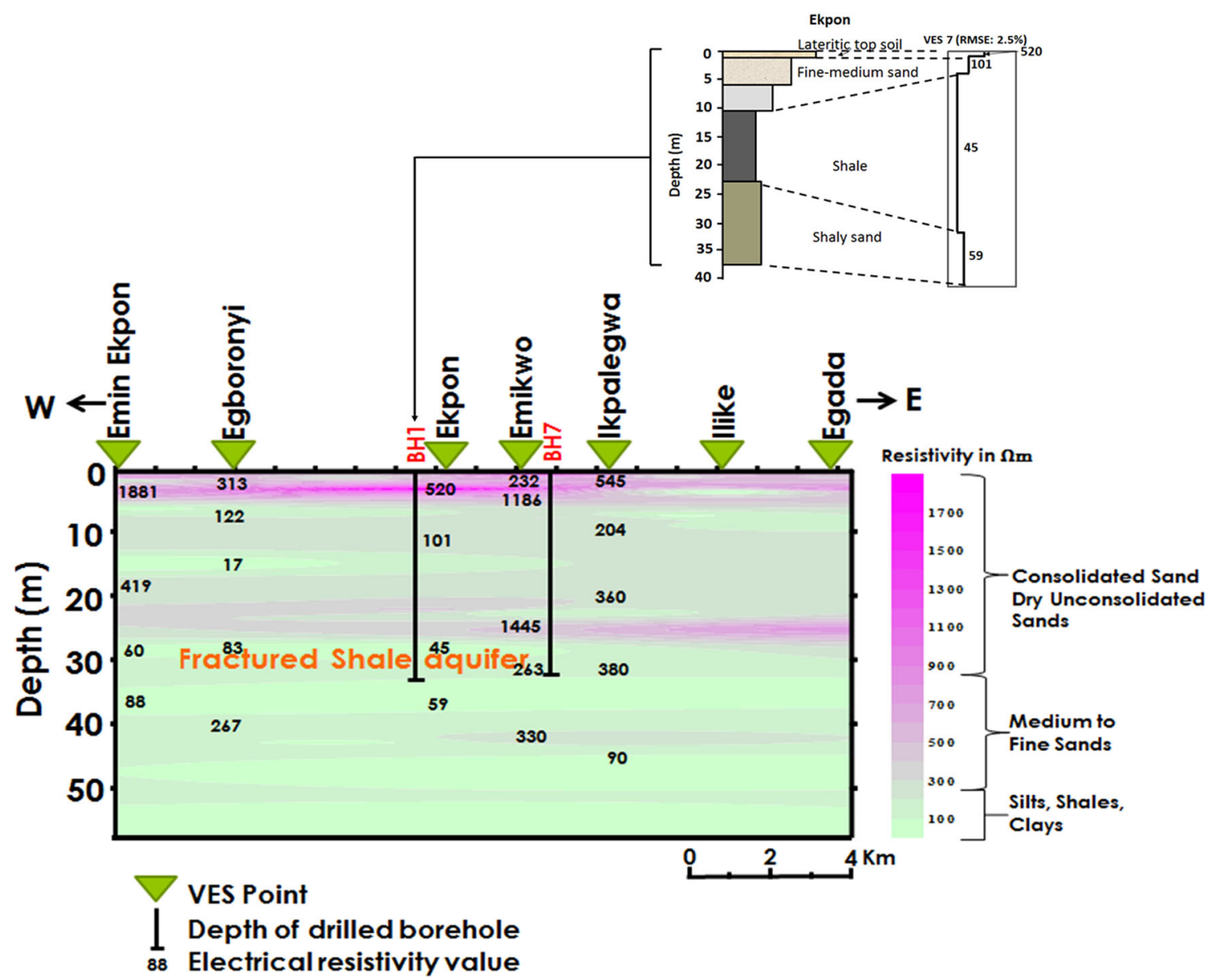

Fig. 4 Electrical resistivity pseudosection oriented E-W, correlated lithologic description, and 1-D inversion model of VES 7

towards the eastern end of the profile. This structure is usually targeted during groundwater exploitation within the area, although its lateral and vertical continuities limit its productivity. This sandy horizon has been reported by Akpan et al. (2013) and Petters (1989) as having moderate groundwater yield and serves as the dominant source of potable water in the area. The sandy-shale unit grades into a highly fractured shale formation, which also serve as the aquifer unit in the area (Ebong et al. 2014). Directly underlying the fractured shale layer is the silty layer which also serves as groundwater exploitation target.

From the electrostratigraphic cross section (Fig. 5), which crosses NSG and EAG, four distinct geoelectric layers were observed. The first-layer resistivities $(148-1881 \Omega \mathrm{m})$ and was interpreted to be a thin (4-6 m) layer of sandy soils with different moisture and texture compositions. The second layer, which consists of sands and consolidated sandstones, has resistivity values that range from 204 to $746 \Omega \mathrm{m}$ and $\sim 34 \mathrm{~m}$ in thickness. This layer is occasionally truncated by layers of fractured shale $(\rho>60 \Omega \mathrm{m})$ of the EAG and some clay $(\rho<60 \Omega \mathrm{m})$ intercalations. An impervious layer, consisting of thick $(\sim 8 \mathrm{~m})$ shales, overlies the fourth layer. The fourth layer, dominated by fine-medium grained sandstone (saturated), underlies the impervious shale unit with moderate resistivity $(121-364 \Omega \mathrm{m})$ values and thicknesses $(5.5-12.0 \mathrm{~m})$. This layer constitutes the aquifer horizon within the southern portion of the study area.

The aquifer horizons, particularly in the northern area, are inhomogeneous and anisotropic. Groundwater flow directions are strongly influenced by variations in topography, textural composition of the aquifer horizon, and tectonic history. Dry season depths to groundwater table vary generally between 25 and $40 \mathrm{~m}$ depending on paleo-tectonic disturbances in the area. These disturbances resulted in the development of secondary aquifer properties, e.g., fractures and joints, and deformation of shales into shalestones, sands into sandstones, and baking/dooming of shaly sediments, which also enhance groundwater transmission and yield (Okereke et al. 1998; Raju and Reddy 1998). In addition, water table levels also respond strongly to seasonal influences. For instance, in rainy 
Fig. 5 Electrical resistivity pseudosection oriented $\mathrm{N}-\mathrm{S}$

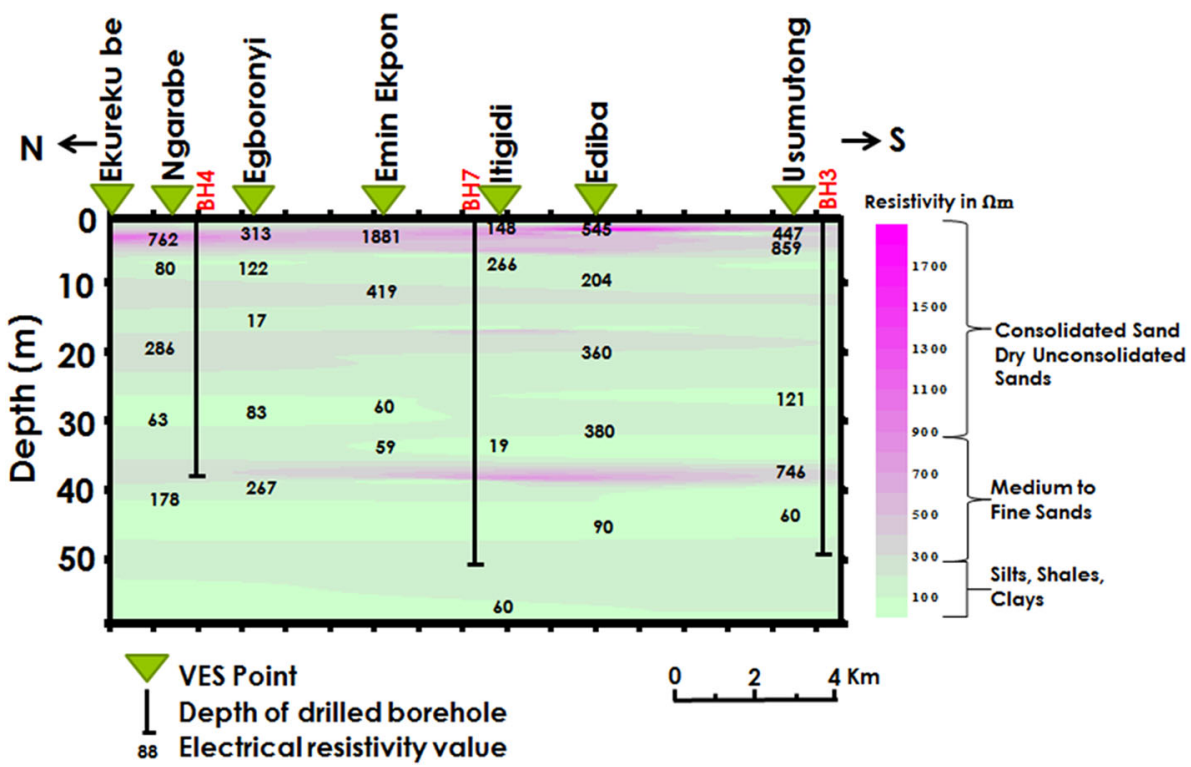

Table 1 Summary of resistivity ranges and lithologic description

\begin{tabular}{ll}
\hline Resistivity $(\mathrm{Ohm}-\mathrm{m})$ & Lithologic description \\
\hline$>50$ & Clay \\
$50-100$ & Silt/shale \\
$100-250$ & Fine sand \\
$250-500$ & Fine-to-medium sand \\
$500-850$ & Medium-to-coarse sand \\
$850-900$ & Consolidated sand \\
$>900$ & Dry unconsolidated sand \\
\hline
\end{tabular}

seasons, groundwater tables are usually high (3-5 $\mathrm{m}$ in the low-lying areas and 10-20 m elsewhere) due to a rise in water levels inside the Cross River which brings about a direct inflow of river water landwards. Table 1 summarizes the shallow subsurface resistivity and lithologic variations of Abi area.

\section{Hydrochemistry and water quality}

The chemical composition of groundwater depends on the soluble products of rocks and soils that it makes contact with, as it circulates within porous and permeable media (Ragunath 1987). The lithologic composition of the vadose zone materials and the rock chemistry of groundwater conduits are potential sources of cation and anion concentrations in the groundwater system. More so, they could be human-induced, either through industrial wastewater seepages, municipal waste, unsewered sanitary facilities, or from soil enhancement chemicals, which when not attenuated during the process of leaching will adversely alter the physical, chemical, and biological characteristics of the groundwater system (Sakthimurugan 1995).
The Pearson's correlation matrix, a bivariate technique usually employed in geochemical analyses to show how well one variable can predict the other was used to establish correlation coefficients of ions in the groundwater samples. Distinct sets of strong relationships were established between the cations and the anions (Table 3). Prior to the computation of the correlation matrix, the data were normalized to take on values between 0.1 and 0.9 using the following equation:

$X_{n}=0.8 \times\left[\frac{\left(X_{i}-X_{\min }\right)}{X_{\max }-X_{\min }}\right]+0.1$

where $X_{n}$ is the normalized value, $X_{i}$ is the measured value, $X_{\max }$ and $X_{\min }$ are maximum and minimum values, respectively. Normalization (scaling) was considered essential to avoid higher values prevailing over lower ones which could lead to saturation. Scaling also makes the values to become dimensionless (Ozcep et al. 2010). The level of relationships obtained from the Pearson correlation matrix varies between -1 and +1 based on the statistical significance of the estimated correlation (Ketata et al. 2011). Correlation coefficients $>0.7$ were considered to be strong, whereas those between 0.5 and 0.7 were considered to have moderate correlation (Giridharan et al. 2008). Negative coefficients were indicative of the fact that the considered variables are evolving in opposite directions. Based on the Douglas and Leo (1977) groundwater chemistry relationships, it was observed that the correlation coefficients of the highly competitive ions were weak, such that $\mathrm{Na}^{+}$with $\mathrm{Mg}^{+}(-0.11), \mathrm{Ca}^{+}$with $\mathrm{Na}^{+}(0.13)$, and $\mathrm{SO}_{4}{ }^{2-}$ with $\mathrm{Cl}^{-}(-3.6)$. In terms of affinity ion relationship, $\mathrm{Ca}^{+}$with $\mathrm{SO}_{4}{ }^{2-}$ were strongly correlated (0.71), whereas other ions, such as $\mathrm{Na}^{+}$with $\mathrm{Cl}^{-}(0.13), \mathrm{Mg}^{2+}$ 
with $\mathrm{SO}_{4}{ }^{2-}(-0.03)$, Na with $\mathrm{HCO}_{3}{ }^{-}(0.25)$, and $\mathrm{K}^{+}$with $\mathrm{HCO}^{-3}$ (0.03), were weak. The non-competitive relationships were also weakly correlated except $\mathrm{HCO}_{3}{ }^{-}$with $\mathrm{Cl}^{-}$ $(-0.50)$.

The Piper diagram (Piper 1944) is the most widely used graphical method for analyzing geochemical data. The diagram, which displayed a diamond-shaped central plot sandwiched between two separate trilinear plots, is reputed for evaluating the relative concentrations of major cations and anions in water samples (Güler et al. 2002). The overall chemical characteristics of the water sample, which is a function of the evolutionary pathways (Freeze and Cherry 1979) or mixture of groundwater with weathered materials from host formations (Ragunath 1987), are expressed by the diagram. Water samples with similar qualities will tend to plot together as groups (Todd and Mays 2005). Figure 6 shows the results of ten sampled borehole water compositions in the area on the Piper diagram. The clusters are indicators of the water type present in the area. The Piper plot showed clear dominance of $\mathrm{Ca}-$ $\mathrm{Mg}-\mathrm{CO}_{3}-\mathrm{HCO}_{3}$ concentration in the water facies. Such water facies have been reported by Handa (1979) to indicate sufficient recharge from fresh water aquifer and water with temporary hardness. Figure 4 shows that alkaline earth metals, e.g., $\mathrm{Ca}^{2+}$ and $\mathrm{Mg}^{2+}$, exceed the alkalis, e.g., $\mathrm{Na}^{+}$and $\mathrm{K}^{+}$. Lower $\mathrm{K}^{+}$in groundwater is due to fixation in the form of clay minerals leading to nutrient loss and resistance to weathering (Kolahchi and Jalali 2006). Weak acids, such as $\mathrm{HCO}_{3}{ }^{-}$, dominate strong acids, e.g., $\mathrm{Cl}^{-}$and $\mathrm{SO}_{2}$, thus, indicating the dominance of alkaline earth metals over bicarbonates (Subba Rao 2002). This also points to exchange of $\mathrm{Na}^{+}$with alkaline earth metals resulting in base exchanged hardened water. This observation is in line with the reports of Akpan et al. (2013) for groundwater within the Ikom Mamfe Embayment.

Groundwater temperatures vary from 26 to $29{ }^{\circ} \mathrm{C}$ (average of $27.5^{\circ} \mathrm{C}$ ). These values are within the WHO (2010) permissible limit of $30{ }^{\circ} \mathrm{C}$ for drinking water. The $\mathrm{pH}$ or proton acidity values of the groundwater range 5.0-8.4 with an average value of 6.8 (Table 1). Groundwater samples with $\mathrm{pH}$ values below 6.5 are acidic which indicates depletion of hydroxide ions in such samples compared to the abundant hydrogen ions present. $40 \%$ of the water sampled are acidic $(\mathrm{pH} \leq 6.5)$ while $60 \%$ were alkaline $(\mathrm{pH}>6.5)$. Areas where the groundwater is acidic could be attributed to anthropogenic activities and indiscriminate sewage disposal. Weathering processes within aquifer horizons could also contribute to the elevated water acidity. Values of groundwater electrical conductivity (EC) which is a measure of the ease, in which water conducts electric current range from 40.0 to $950 \mu \mathrm{S} / \mathrm{cm}$ at $25^{\circ} \mathrm{C}$. These observations are below WHO (2010) tolerable limit of $1400 \mu \mathrm{S} / \mathrm{cm}$ for drinking and agricultural water needs. EC values approximately capture the total amount of dissolved substances in water. It depends on temperature, concentration, and type of ions present (Hem 1989). When
Fig. 6 Piper diagram for groundwater investigation in Abi

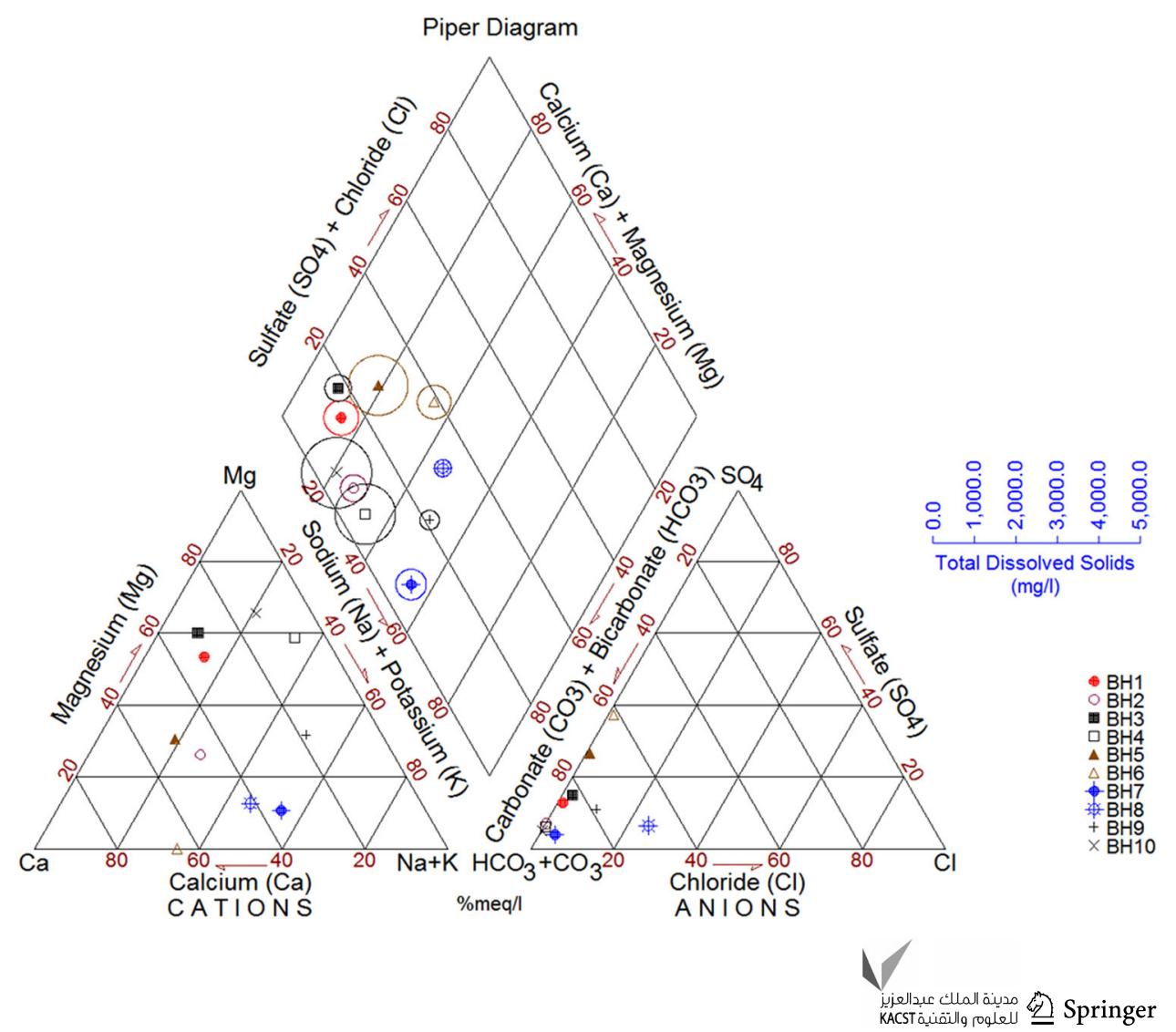


Table 2 Results of physico-chemical analysis

\begin{tabular}{|c|c|c|c|c|c|c|c|c|c|c|c|c|c|c|}
\hline \multirow{2}{*}{$\begin{array}{l}\text { Sample } \\
\text { location }\end{array}$} & \multicolumn{2}{|c|}{$\begin{array}{l}\text { Depth to water } \\
\text { table }(\mathrm{m})\end{array}$} & \multicolumn{2}{|c|}{$\begin{array}{l}\text { Total hardness } \\
(\mathrm{mg} / \mathrm{l})\end{array}$} & \multicolumn{2}{|c|}{$\begin{array}{l}\text { Salinity as } \mathrm{NaCl} \\
(\mathrm{mg} / \mathrm{l})\end{array}$} & \multirow{2}{*}{$\begin{array}{l}\begin{array}{l}\text { EC (iS/ } \\
\mathrm{cm})\end{array} \\
688.9\end{array}$} & $\mathrm{pH}$ & $\begin{array}{l}\text { Colour }(\mathrm{Pt}- \\
\mathrm{Co})\end{array}$ & \multirow{2}{*}{$\begin{aligned} \begin{array}{l}\text { TDS } \\
(\mathrm{mg} / \mathrm{l})\end{array} \\
461.6\end{aligned}$} & \multirow{2}{*}{$\begin{array}{l}\mathrm{Na} \\
18.0\end{array}$} & \multirow{2}{*}{$\frac{\mathrm{K}}{2.10}$} & \multirow{2}{*}{$\begin{array}{l}\text { Ca } \\
37.6\end{array}$} & \multirow{2}{*}{$\begin{array}{l}\mathrm{Mg} \\
37.90\end{array}$} \\
\hline & 44.0 & & 250.0 & & 3.78 & & & 6.8 & 2.7 & & & & & \\
\hline $\mathrm{BH} 2$ & 17.0 & & 50.0 & & 0.83 & & 62.8 & 6.5 & 1.4 & 41.2 & 16.4 & 1.10 & 25.6 & 8.70 \\
\hline $\mathrm{BH} 3$ & 101.0 & & 63.0 & & 0.45 & & 467.0 & 7.0 & 2.1 & 313.2 & 11.3 & 1.20 & 33.6 & 40.30 \\
\hline BH4 & 46.0 & & 185.0 & & 4.70 & & 608.0 & 7.1 & 4.3 & 407.5 & 19.0 & 1.60 & 4.0 & 18.50 \\
\hline BH5 & 75.0 & & 120.0 & & 7.84 & & 950.0 & 8.4 & 4.8 & 623.8 & 17.6 & 5.30 & 48.8 & 17.90 \\
\hline BH6 & 48.0 & & 102.0 & & 1.18 & & 341.0 & 7.2 & 1.9 & 156.9 & 18.0 & 5.70 & 35.2 & 0.01 \\
\hline BH7 & 38.0 & & 56.0 & & 0.21 & & 40.0 & 5.5 & 1.5 & 30.0 & 12.0 & 2.60 & 7.6 & 1.40 \\
\hline BH8 & 18.0 & & 83.0 & & 0.30 & & 89.1 & 5.0 & 1.2 & 48.9 & 18.0 & 2.20 & 15.2 & 2.81 \\
\hline BH9 & 41.0 & & 58.0 & & 0.12 & & 51.0 & 5.9 & 1.3 & 28.5 & 25.0 & 0.50 & 7.2 & 7.49 \\
\hline BH10 & 59.0 & & 216.0 & & 4.60 & & 330.0 & 8.4 & 4.2 & 193.0 & 23.0 & 1.90 & 12.0 & 35.10 \\
\hline Maximum & 101.0 & & 250.0 & & 7.84 & & 950.0 & 8.4 & 4.8 & 623.8 & 25.0 & 5.70 & 48.8 & 40.30 \\
\hline Minimum & 17.0 & & 50.0 & & 0.12 & & 40.0 & 5.0 & 1.2 & 28.5 & 11.3 & 0.50 & 4.0 & 0.01 \\
\hline Average & 48.7 & & 118.3 & & 2.40 & & 362.8 & 6.8 & 2.5 & 230.5 & 17.8 & 2.42 & 22.7 & 17.01 \\
\hline $\begin{array}{l}\text { WHO } \\
\qquad(2010)\end{array}$ & - & & - & & - & & 1400.0 & $6.5-8.5$ & 15.0 & 1000.0 & 50.0 & 12.00 & 200.0 & 150.00 \\
\hline Sample locati & & $\mathrm{NH}_{4}$ & $\mathrm{HCO}_{3}$ & $\mathrm{Cl}$ & $\mathrm{SO}_{4}$ & $\mathrm{NO}_{2}$ & $\mathrm{NO}_{3}$ & $\mathrm{PO}_{4}$ & $\mathrm{Fe}$ & $\mathrm{Mn}$ & $\mathrm{Zn}$ & & SAR & $\mathrm{Na} \%$ \\
\hline BH1 & & 0.15 & 135.20 & 3.50 & 48.0 & 0.17 & 0.12 & 2.49 & 0.01 & 0.00 & 0.04 & & 2.93 & 21.03 \\
\hline $\mathrm{BH} 2$ & & 0.18 & 121.40 & 0.50 & 22.0 & 0.19 & 0.07 & 1.56 & 0.05 & 0.00 & 0.05 & & 3.96 & 33.78 \\
\hline BH3 & & 0.13 & 92.40 & 4.80 & 40.0 & 0.04 & 0.02 & 2.32 & 0.06 & 0.00 & 0.00 & & 1.86 & 14.47 \\
\hline BH4 & & 0.28 & 312.90 & 2.60 & 48.0 & 0.09 & 0.11 & 9.00 & 0.01 & 0.03 & 0.08 & & 5.66 & 47.8 \\
\hline BH5 & & 0.11 & 216.60 & 4.10 & 190.0 & 0.27 & 0.24 & 2.24 & 0.15 & 0.00 & 0.00 & & 3.05 & 25.56 \\
\hline BH6 & & 0.09 & 98.00 & 4.00 & 142.0 & 0.45 & 0.49 & 1.45 & 0.00 & 0.00 & 0.80 & & 4.29 & 40.23 \\
\hline $\mathrm{BH} 7$ & & 0.18 & 157.80 & 11.50 & 16.0 & 0.02 & 0.02 & 1.46 & 0.03 & 0.00 & 0.22 & & 5.66 & 61.86 \\
\hline BH8 & & 0.32 & 58.00 & 37.50 & 13.0 & 0.01 & 0.07 & 1.58 & 0.05 & 0.00 & 0.20 & & 6 & 52.87 \\
\hline BH9 & & 0.31 & 76.00 & 17.50 & 25.0 & 0.03 & 0.03 & 1.62 & 0.01 & 0.02 & 0.12 & & 9.22 & 63.45 \\
\hline BH10 & & 0.32 & 365.40 & 2.50 & 45.0 & 0.08 & 0.10 & 0.10 & 0.02 & 0.01 & 0.05 & & 4.74 & 34.58 \\
\hline Maximum & & 0.32 & 365.40 & 37.50 & 190.0 & 0.45 & 0.49 & 9.00 & 0.15 & 0.03 & 0.80 & & 9.22 & 63.45 \\
\hline Minimum & & 0.09 & 58.00 & 0.50 & 13.0 & 0.01 & 0.02 & 0.10 & 0.00 & 0.00 & 0.00 & & 1.86 & 14.47 \\
\hline Average & & 0.21 & 163.37 & 8.85 & 58.9 & 0.14 & 0.13 & 2.38 & 0.04 & 0.01 & 0.16 & & 4.74 & 39.56 \\
\hline WHO (2010) & & - & - & 250.00 & 250.0 & 3.00 & 50.00 & - & 0.30 & 0.05 & 5.00 & & - & - \\
\hline
\end{tabular}

the EC of water changes significantly over time in an area or from one point to another within a locality, it may be inferred that the water quality will also change, occasioned by changes in the amount of dissolved substances present as both are directly related. TDS values, which represent the weight of residual materials deposited after the water samples, have evaporated, vary from 28.5 to $623.8 \mathrm{mg} / \mathrm{l}$ with an average of $204.8 \mathrm{mg} / \mathrm{l}$ (Table 2). These observations show that the TDS values are within the WHO (2010)'s acceptable limit of $1000 \mathrm{mg} / \mathrm{l}$ for domestic and agricultural water needs. Zones with high aquifer resistivities, prevalent outside argillaceous sediments-enriched EAG Formation, are characterised by low TDS $(<50 \mathrm{mg} / \mathrm{l})$ and EC $(<100 \mu \mathrm{S} / \mathrm{cm})$ values, and vice versa. Such lowresistivity zones reflect increased total solute content resulting from dissolution of some minerals, such as gypsum and halite. The water colour values range from 1.2 to $4.8 \mathrm{Pt}-\mathrm{Co}$, which are below the WHO (2010) standard colour of $15.00 \mathrm{Pt}-\mathrm{Co}$. These variations were attributed to changes in the amount of clay minerals, ferruginous materials and schists that have dissolved in the groundwater. The localized high values of colour, $\mathrm{EC}, \mathrm{pH}$, and TDS in areas around Imabana are indicators of the abundant free ions present in the water. This can be attributed to the dissolution between water and existing soluble rock masses (Hem 1989).

The concentrations of cations: $\mathrm{Na}^{+}, \mathrm{Ca}^{2+}, \mathrm{K}^{+}, \mathrm{Mg}^{2+}$, $\mathrm{Mn}^{2+}$, and $\mathrm{Zn}^{+}$vary, respectively, from 11.3-25.0, $4.0-48.8, \quad 0.5-5.7, \quad 0.01-40.30, \quad 0.01-0.03$, and $0.04-0.80 \mathrm{mg} / \mathrm{l}$ (Table 3). Increase in the concentrations of $\mathrm{Na}^{+}, \mathrm{Ca}^{2+}$, and $\mathrm{Mg}^{2+}$ was traceable to dominant ionic compositions of major rock types in the sedimentary 
Table 3 Pearson's correlation matrix of chemical constituents of groundwater in Abi aquifers

\begin{tabular}{|c|c|c|c|c|c|c|c|c|c|c|c|c|c|c|}
\hline & $\mathrm{Na}$ & $\mathrm{K}$ & $\mathrm{Ca}$ & $\mathrm{Mg}$ & $\mathrm{NH}_{4}$ & HCO3 & $\mathrm{Cl}$ & $\mathrm{SO}_{4}$ & $\mathrm{NO}_{2}$ & $\mathrm{NO}_{3}$ & $\mathrm{PO}_{4}$ & $\mathrm{Fe}$ & $\mathrm{Mn}$ & $\mathrm{Zn}$ \\
\hline $\mathrm{Na}$ & 1.00 & & & & & & & & & & & & & \\
\hline K & 0.27 & 1.00 & & & & & & & & & & & & \\
\hline $\mathrm{Ca}$ & 0.15 & 0.73 & 1.00 & & & & & & & & & & & \\
\hline $\mathrm{Mg}$ & 0.29 & 0.11 & 0.50 & 1.00 & & & & & & & & & & \\
\hline $\mathrm{NH}_{4}$ & 0.73 & -0.13 & -0.29 & 0.21 & 1.00 & & & & & & & & & \\
\hline $\mathrm{HCO}_{3}$ & 0.53 & 0.37 & 0.17 & 0.57 & 0.48 & 1.00 & & & & & & & & \\
\hline $\mathrm{Cl}$ & 0.43 & 0.28 & 0.14 & 0.03 & 0.63 & 0.08 & 1.00 & & & & & & & \\
\hline $\mathrm{SO}_{4}$ & 0.37 & 0.92 & 0.80 & 0.29 & -0.13 & 0.45 & 0.19 & 1.00 & & & & & & \\
\hline $\mathrm{NO}_{2}$ & 0.37 & 0.86 & 0.77 & 0.19 & -0.16 & 0.34 & 0.13 & 0.87 & 1.00 & & & & & \\
\hline $\mathrm{NO}_{3}$ & 0.43 & 0.90 & 0.67 & 0.15 & -0.04 & 0.38 & 0.28 & 0.87 & 0.96 & 1.00 & & & & \\
\hline $\mathrm{PO}_{4}$ & 0.37 & 0.32 & 0.23 & 0.39 & 0.39 & 0.60 & 0.35 & 0.42 & 0.39 & 0.43 & 1.00 & & & \\
\hline $\mathrm{Fe}$ & 0.20 & 0.60 & 0.71 & 0.38 & 0.09 & 0.39 & 0.43 & 0.71 & 0.47 & 0.43 & 0.39 & 1.00 & & \\
\hline $\mathrm{Mn}$ & 0.69 & 0.08 & -0.11 & 0.31 & 0.68 & 0.65 & 0.35 & 0.24 & 0.19 & 0.27 & 0.81 & 0.16 & 1.00 & \\
\hline $\mathrm{Zn}$ & 0.37 & 0.74 & 0.39 & -0.04 & 0.11 & 0.21 & 0.49 & 0.59 & 0.78 & 0.87 & 0.38 & 0.21 & 0.30 & 1.00 \\
\hline
\end{tabular}

formations present in the area (Figs. 1b, 6). The various aquifer horizons and their vadose zone materials are rich in silicate minerals, thus the groundwater captures the abundant $\mathrm{Ca}^{2+}, \mathrm{Mg}^{2+}$ and $\mathrm{Na}^{+}$, which probably are fallouts from calcite and silicate weathering processes (Holland 1978; Hem 1989). The concentration of potassium ion in groundwater is low, perhaps, due to the resistance of K-feldspathic-enriched rocks to weathering (Kolahchi and Jalali 2006). Interactions of carbonate rocks with groundwater (percolating and water circulating inside aquifers) alter the chemistry of the groundwater system. Aquifer water-rock interaction also occurs during other processes, such as dolomitization, albitization of feldspars, and cation exchange in clay minerals. Possible sources of such cation concentrations in groundwater are calcite $\left(\mathrm{CaCO}_{3}\right)$ and dolomite $\left(\mathrm{CaMg}\left(\mathrm{CO}_{3}\right)_{2}\right)$ in rocks and soils (Younger 2007). Akpan et al. (2013) and Tijani (2004) have also reported similar cases of increased concentration of these cations in the other parts of the Mamfe Embayment and Benue Trough, respectively. Other causes of elevated cation concentration in groundwater include indiscriminate disposal of industrial waste water and the application of soil fertility enhancement chemicals, such as NPK [i.e., nitrogen $(15 \%)$, phosphorus (30\%), and potassium (55\%)]; composts, pesticides, herbicides, and soil fumigants. Such chemicals are capable of passing through preferential pathways in the vadose zone, especially, if the vadose zone materials lack the capacity to naturally attenuate the vertical flow of such contaminants (Akpan et al. 2014). Variations in the concentrations of major anions: $\mathrm{Cl}^{-}$, $\mathrm{HCO}_{3}{ }^{-}, \mathrm{NO}_{3}{ }^{2-}, \mathrm{NO}_{2}{ }^{2-}, \mathrm{SO}_{4}{ }^{2-}$, and $\mathrm{PO}_{4}{ }^{3-}$ were 0.5-37.5, 58.0-365.4, $0.02-0.49, \quad 0.01-0.45, \quad 13.0-190.0$, and 0.1-9.0 mg/l (Table 3). The low concentrations of $\mathrm{NO}_{3}$ were attributed to the influence of denitrification prevalent in the area (Akpan et al. 2014). $\mathrm{Cl}^{-}$and $\mathrm{HCO}_{3}{ }^{-}$are the most dominant ions, and their abundance is indicative of the various salinization sources (Akpan et al. 2013).

\section{Drinking and irrigation water quality assessment}

Water use for drinking and domestic purposes will depend on hardness (Karanth 1987). Hardness of water could be temporal due to the presence of carbonate and bicarbonate and permanent, if sulphates and chlorides of calcium and magnesium exist (Fig. 4). The high concentrations of calcium and magnesium are traceable to the siltstones and other calcic and dolomitic components present in the area (Ebong et al. 2014; Haritash et al. 2008). Schroeder (1960) reported that hard water can cause some heart diseases and also requires more detergents to foam. The maximum permissible limit of total hardness for drinking is $500 \mathrm{mg} / \mathrm{l}$ and the WHO desirable limit is $100 \mathrm{mg} / \mathrm{l}$. The TH classification based on Sawyer and McCartly (1967) showed that $\mathrm{BH} 1, \mathrm{BH} 4$, and $\mathrm{BH} 10$ which constitute $30 \%$ and $\mathrm{BH} 5$, $\mathrm{BH} 6$, and $\mathrm{BH} 8$ (30\%) of the water are hard and moderately hard, respectively. $\mathrm{BH} 2, \mathrm{BH} 3, \mathrm{BH} 7$, and $\mathrm{BH} 9$ (i.e., $40 \%$ ) are soft (Table 3).

In general, groundwater considerations for irrigation purposes depend on the effects of mineral constituents of soils and plants (Ketata et al. 2011). Presence of excess dissolved ions in irrigation water affects agricultural soils and plants both physically and chemically, hence could lead to low productivity. The suitability of groundwater for any purpose will depend on the amount of TDS, which should be below $500 \mathrm{mg} / \mathrm{l}$ (Freeze and Cherry 1979). Excess sodium concentration in soils can change its properties, thereby reducing its permeability (Todd and Mays 2005). The SAR, which indicates the degree to 
which irrigation water can engage in cation exchange reaction, was employed in this study. Excess sodium concentration in water can produce undesirable effects, like changes in soil properties and reduction in soil permeability, when used for irrigation. These reactions can be used to estimate the rate, at which peculating water engages in cation exchange reaction in soils (Todd and Mays 2005). The replacement of calcium and magnesium by sodium in soils causes damage to the soil structure by making it compact and impermeable (Raju 2007). The spatial distribution of SAR shows that their concentrations are high in the western part of the study area around Igoni-igoni, Itigidi, and decreases towards Agbara in the northern part (Figs. 7, 8). Salinity hazards were low in BH9, $\mathrm{BH} 8, \mathrm{BH} 7, \mathrm{BH} 10, \mathrm{BH} 6$, and $\mathrm{BH} 4$, while in $\mathrm{BH} 3$ and $\mathrm{BH} 1$, it was high and very high in BH5. Distribution of permeability indices reveals that groundwater quality at borehole locations $\mathrm{BH} 1, \mathrm{BH} 2, \mathrm{BH} 3, \mathrm{BH} 5, \mathrm{BH} 6, \mathrm{BH} 7$, and BH8 is of Class 1 ( $\mathrm{PI}<25 \%)$, while $\mathrm{BH} 4, \mathrm{BH} 9$, and BH10 were of Class II (PI $>25 \%$ ). The water quality classification for irrigation purposes performed using the Wilcox plot (Wilcox 1955) technique shows that all the groundwater sampled were below permissible limit (Fig. 9). Na \% varies from a low of $<15 \%$ around
Usumutong area in the south and to $\sim 60 \%$ around Itigidi in the central zone (Figs. 8, 9). Hence, the groundwater system is suitable for irrigation purpose (Table 4).

\section{Recommended aquifer management practices}

The following aquifer management practices have been recommended to sustain groundwater quality in the area.

1. The use of inorganic chemical fertilizers, especially those enriched with nitrogenous compounds around the low-lying northern zones should be properly regulated. This approach is the most practically acceptable and standard measure in abating groundwater pollution resulting from the application of fertilizers, in such shallow aquifer areas.

2. The period of application of inorganic fertilizers should be carefully planned, so that it does not correspond with the peak period of leaching, which in the area will coincide with the peak period of rainfall (June and July). Thus, fertilizer application must be done at the period of maximum crop uptake.

3. The traditional land-use plans, such as the shifting cultivation, should be encouraged.
Fig. 7 Plots of calculated values of SAR and EC of groundwater sample

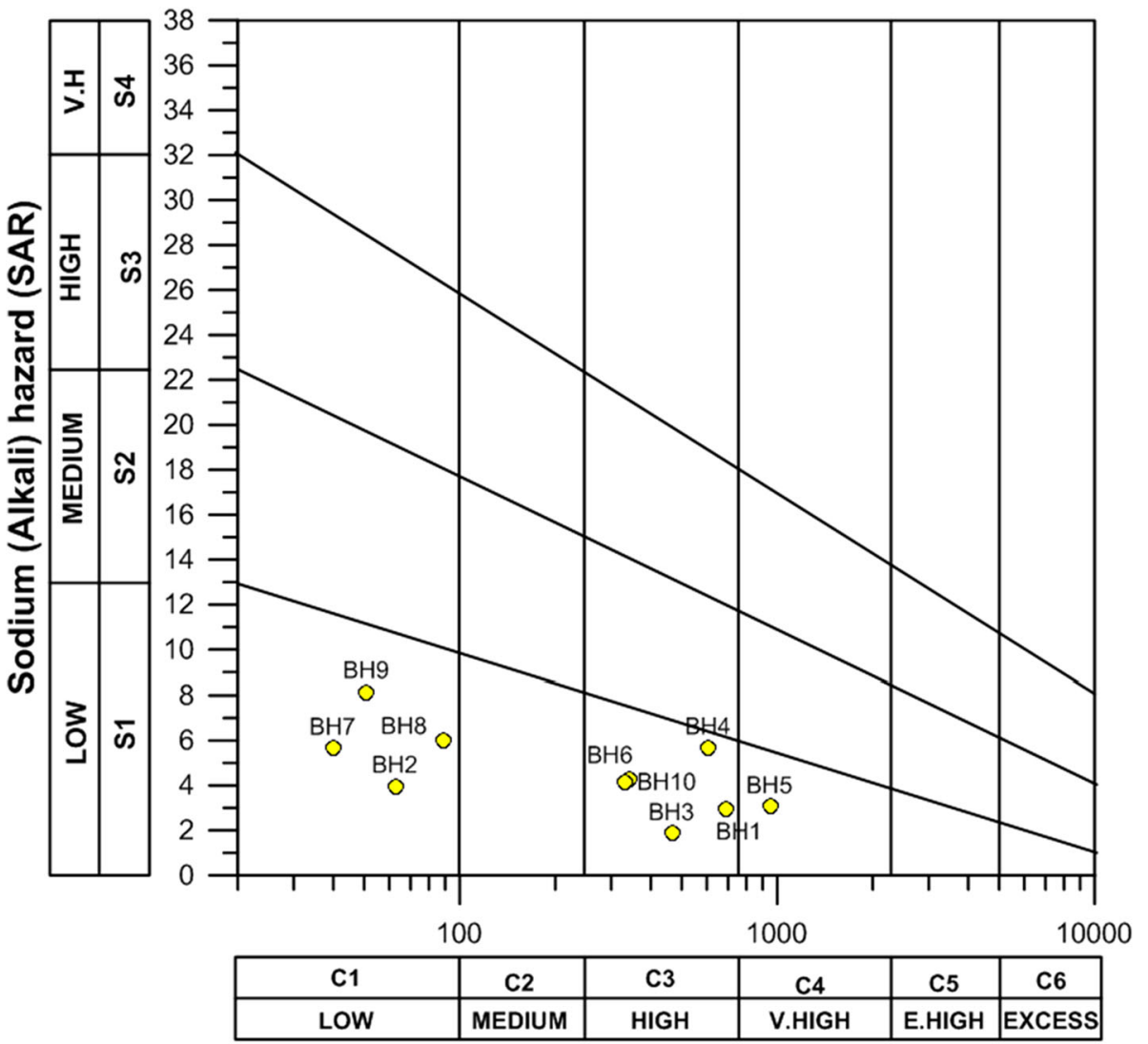

Salinity hazard (Electrical Conductivity $\mu \mathrm{S} / \mathrm{cm}$ at $25^{\circ} \mathrm{C}$ ) 

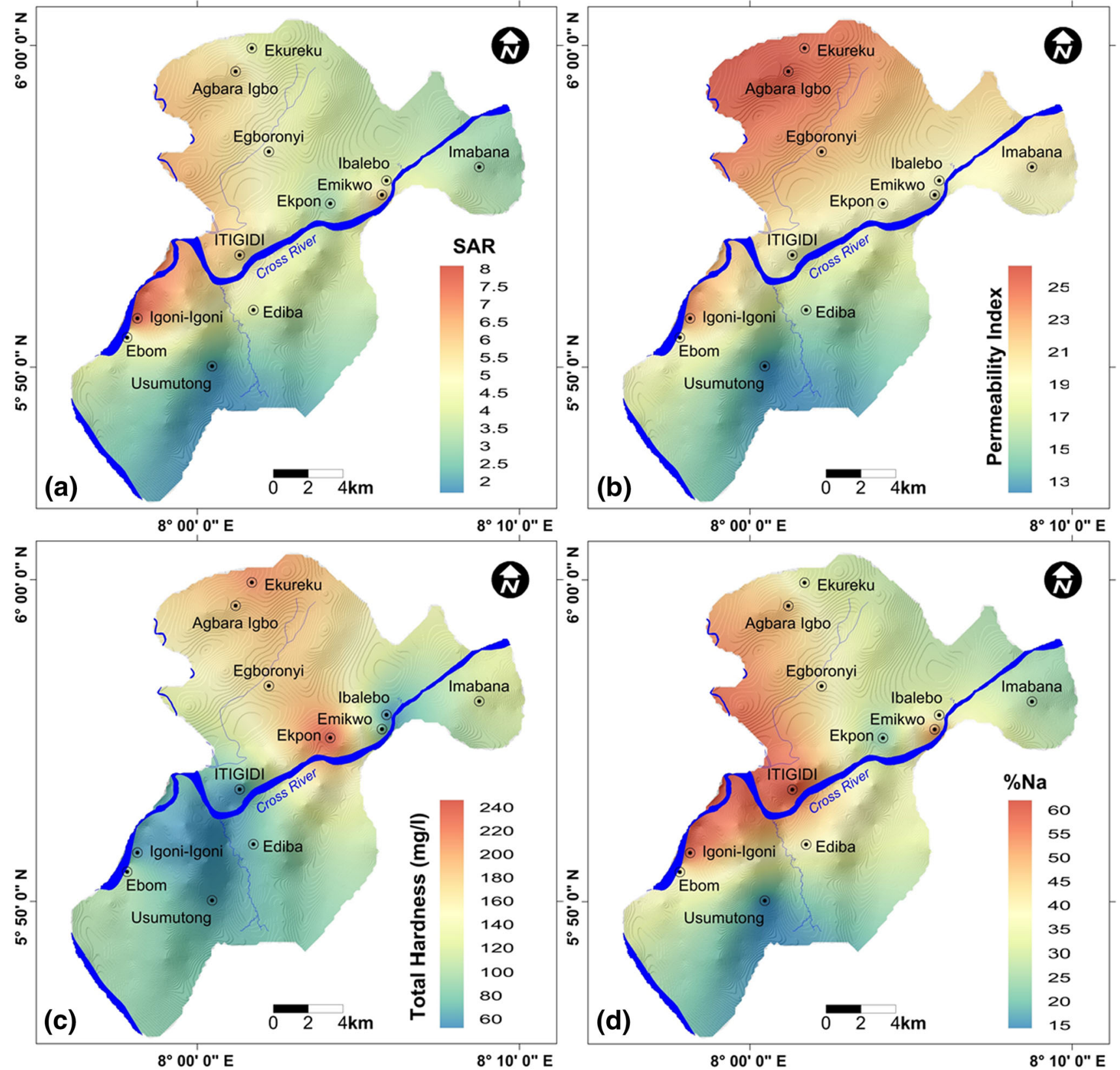

Fig. 8 Iso-concentration maps of the spatial distribution of sodium absorption ratio (a), permeability index (b), total hardness (c), and percent sodium $(\mathbf{d})$

4. Regulations to protect important water supply aquifers should be adopted.

5. The adoption of good sanitary habits and practices. Septic system management practices, such as periodic pumping and inspection (e.g., at intervals of 5 years), should be adopted.

6. Chemicals should not be dumped on drains or on the ground. Environmentally friendly methods of waste management, such as waste recycling, should be adopted to reduce the impact of industrial wastes on the environment.

\section{Conclusion}

Results obtained from electrical resistivity data correlate with geologic logs, although not sufficiently and were used to delineate the lithostratigraphic units. The groundwater quality was assessed based on water samples collected from ten randomly distributed borehole within the study area. The geophysical results showed the lateral and vertical distribution of sedimentary units of the Asu River Group, fractured sandstones, shales, and siltstones of Eze- 


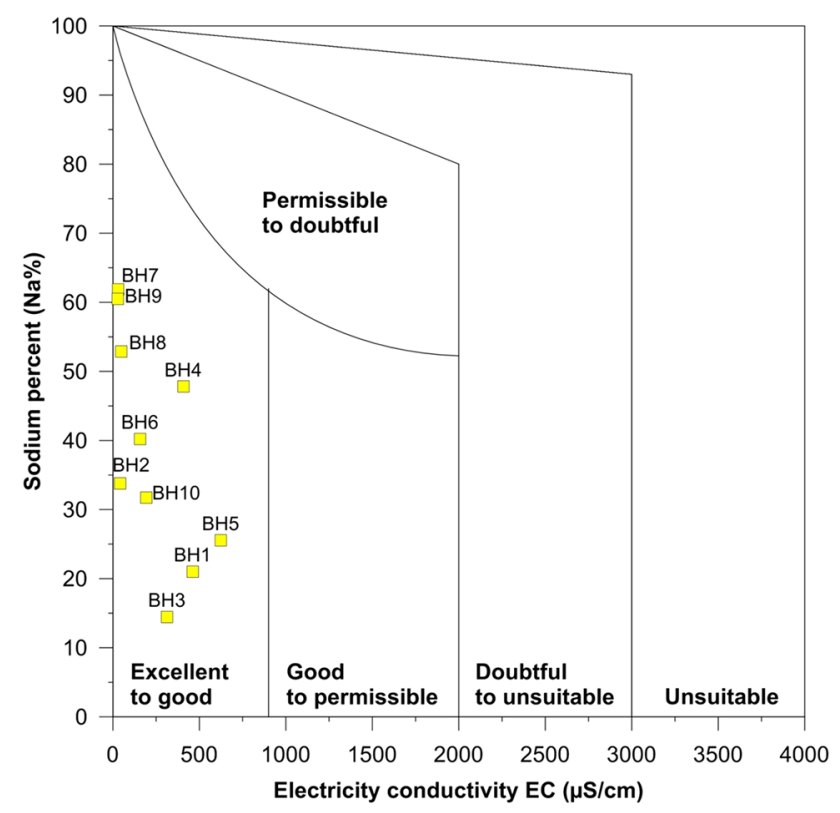

Fig. 9 Wilcox diagram irrigation water classification [After Wilcox (1948)]

Table 4 Groundwater classification based on total hardness [after Sawyer and McCartly 1967]

\begin{tabular}{lllll}
\hline $\begin{array}{l}\text { Total hardness } \\
(\mathrm{TH}) \text { as } \\
\mathrm{CaCO}_{3}(\mathrm{mg} / \mathrm{l})\end{array}$ & $\begin{array}{l}\text { Type of } \\
\text { water }\end{array}$ & $\begin{array}{l}\text { Sample } \\
\text { numbers }\end{array}$ & $\begin{array}{l}\text { Number } \\
\text { of samples }\end{array}$ & $\begin{array}{l}\text { \% of } \\
\text { samples }\end{array}$ \\
\hline$<75$ & Soft & $\begin{array}{c}\text { BH2, BH3, } \\
\text { BH7, BH9 }\end{array}$ & 4 & 40 \\
$75-150$ & $\begin{array}{c}\text { Moderately } \\
\text { hard }\end{array}$ & $\begin{array}{c}\text { BH5, BH6, BH8 } \\
\text { Hard }\end{array}$ & $\begin{array}{c}\text { BH1, BH4, } \\
\text { BH10 }\end{array}$ & 30 \\
$150-300$ & $\begin{array}{c}\text { Very hard } \\
>300\end{array}$ & - & - & 30 \\
\hline
\end{tabular}

Aku Group which serves as the aquifer unit having moderate groundwater yields and the Nkporo Shale Formation. These formations are known to be rich in silicate minerals and groundwater from such aquifers show dominance in $\mathrm{Ca}^{2+}, \mathrm{Mg}^{2+}$, and $\mathrm{Na}^{+}$, suggested to have resulted from silicate weathering processes. These cations balanced the consumption of $\mathrm{H}^{+}$during the hydrolytic alteration of silicate minerals. The geochemical analysis of groundwater samples revealed dominant calcium-magnesium-carbonate-bicarbonate water facies. In general, water facies in the area are influenced by regional geology and showed three distinct classes with amount of low-sodium (S1) and can be used for irrigation with no risk of developing harmful levels of exchangeable $\mathrm{Na}^{+}$. Based on the salinity value and the concentration of sodium, waters are classified as follows: (1) Low salinity (C1) and low-sodium (S1) water that can be used for irrigating most of the crops on permeable soils that permits leaching. (2) High salinity (C3) and low-sodium (S1) water, adequate for moderate salt tolerance plants on soils with moderate permeability leaching potentials. (3) Very high salinity (C4) and lowsodium (S1) water which cannot be used on soils with restricted drainage. The results of the physico-chemical analyses of the groundwater when compared with standards for drinking and agricultural water uses were found to be good, since the results were below permissible limits. The groundwater system was observed to be fresh and is, consequently, suitable for domestic uses, drinking, and irrigation purposes. Although this approach can provide reliable results that can serve as the initial guide to the distribution, availability, and quality of groundwater in the area, it is limited due to paucity of hydrochemical data.

Acknowledgments The authors are thankful to the Cross River State Rural Water Supply and Sanitation Agency (CRS-RUWATSSA) and the Cross River State Community and Rural Development Agency (CRSCRDA) for freely releasing the borehole data used in this study. We also thank Dr. Ferid Dhahri and the other anonymous reviewers for their constructive comments, suggestions and contributions, which have greatly improved the quality of the original manuscript.

Open Access This article is distributed under the terms of the Creative Commons Attribution 4.0 International License (http:// creativecommons.org/licenses/by/4.0/), which permits unrestricted use, distribution, and reproduction in any medium, provided you give appropriate credit to the original author(s) and the source, provide a link to the Creative Commons license, and indicate if changes were made.

\section{References}

Akpan AE, Ugbaja AN, George NJ (2013) Integrated geophysical, geochemical and hydrogeological investigation of shallow groundwater resources in parts of the Ikom-Mamfe Embayment and the adjoining areas in Cross River State, Nigeria. J Environ Earth Sci 70:1435-1456

Akpan AE, Ebong ED, Ekwok SE (2014) Assessment of the state of soils, shallow sediments and groundwater salinity in Abi, Cross River State, Nigeria. J Environ Earth Sci. doi:10.1007/s12665015-4014-6

Akpan AE, Ebong ED, Emeka CN (2015) Exploratory assessment of groundwater vulnerability to pollution in $\mathrm{Abi}$, southeastern Nigeria using geophysical and geological techniques. J Environ Monit Assess 187(4):4380. doi:10.1007/s10661-015-4380-2

APHA (1995) Standard methods for the examination of water and waste water, 19th edn. American Public Health Association, Washington, DC

Bathrellos GD, Skilodimou HD, Kelepertsis A, Alexakis D, Chrisanthaki I, Archonti D (2008) Environmental research of groundwater in the urban and suburban areas of Attica region, Greece. Environ Geol 56(1):11-18

Benkhelil J (1982) Benue trough and Benue chain. Geol Mag Niger 119:115-168

Douglas EB, Leo WN (1977) Hydrogeochemical relationships using partial correlation coefficient. Water Resour Bull 13:843-846

Ebong ED, Akpan AE, Onwuegbuche AA (2014) Estimation of geohydraulic parameters from fractured shales and sandstone 
aquifers of Abi (Nigeria) using electrical resistivity and hydrogeologic measurements. J Afr Earth Sc 96:99-109

Ekwueme BN (2003) The Precambrian geology and evolution of the Southeastern Nigeria basement complex. University of Calabar Press, Nigeria

Ekwueme BN, Nyong EE, Petters SW (1995) Geological excursion guidebook to Oban Massif, Calabar Flank and Mamfe Embayment, Southeastern, Nigeria. Dechord Press, Calabar

Eseme E, Agyingi CM, Foba-Tendo J (2002) Geochemistry and genesis of brine emanations from Cretaceous strata of the Mamfe Basin, Cameroon. J Afr Earth Sci 35:467-476

Etuk EE, Ukpabi N, Ukaegbu VU, Akpabio IO (2008) Structural evolution, magmatism and effects of hydrocarbon maturation in Lower Benue Trough, Nigeria: a case study of Lokpaukwu, Uturu and Ishiagu. Pac J Sci Technol 9(2):526-532

Freeze RA, Cherry JA (1979) Groundwater. Prentice Hall, Englewood Cliffs, New Jersey

Gemail KS, El-Shishtawy AM, El-Alfy M, Ghoneim MF, Abd ElBary MH (2011) Assessment of aquifer vulnerability to industrial waste water using resistivity measurements: a case study, along El-Gharbyia main drain, Nile Delta, Egypt. J Appl Geophys 75:140-150

Giridharan L, Venugopal T, Jayaprakash M (2008) Evaluation of the seasonal variation on the geochemical parameters and quality assessment of the groundwater in the proximity of River Cooum, Chennai, India. J Environ Monit Assess 143:161-178

Güler C, Thyne GD, McCray JE, Turner AK (2002) Evaluation of graphical and multivariate statistical methods for classification of water chemistry data. Hydrogeol J 10:455-474

Handa BK (1979) Groundwater pollution in India. In: Proceedings of National Symposium on Hydrology. IAHS, Publication University of Roorkee, India, pp 34-49

Haritash AK, Kaushik CP, Kaushik A, Kansal A, Kumar YA (2008) Suitability assessment of groundwater for drinking, irrigation and industrial use in some North Indian villages. J Environ Monit Assess 145:397-406

Hem JD (1989) Study and interpretation of the chemical characteristics of natural water, 3rd edn. US Geological Survey WaterSupply Paper 2254, p 263

Holland HD (1978) The chemistry of the atmosphere and oceans. Wiley, New York, p 351

Inman JR (1975) Resistivity inversion with ridge regression. Geophysics 40:798-817

Inoubli N, Gouasmia M, Gasmi M, Mharndi A, Ben Dhia H (2006) Integration of geological, hydrochemical and geophysical methods for prospecting thermal water resources: the case of the Hmeima region (central-western Tunisia). J Afr Earth Sci 46(3):180-186

Karanth KR (1987) Groundwater assessment development and management. Tata Mc Graw-Hill, New Delhi, p 720

Ketata M, Gueddari M, Bouhlila R (2011) Suitability assessment of shallow and deep groundwaters for drinking and irrigation use in the El Khairat aquifer (Enfidha, Tunisian Sahel) Environmental. Earth Sci. doi:10.1007/s12665-011-1091-z

Kolahchi Z, Jalali M (2006) Effect of water quality on the leaching of potassium from sandy soil. J Arid Environ 68:624-639

Massoud U, Santos F, Khalil MA, Taha A, Abbas AM (2010) Estimation of aquifer hydraulic parameters from surface geophysical measurements: a case study of the Upper Cretaceous aquifer, central Sinai, Egypt. Hydrogeol J 18:699-710

Mhamdi A, Dhahri F, Gouasmia M, Moumni L, Mohamed S (2015) Groundwater salinization survey of the Upper CretaceousMiocene Complexe terminal aquifer in the Sabaa Biar area of southwestern Tunisia. J Afr Earth Sci 112:83-92

Minsley BJ, Ajo-Franklin J, Mukhopadhyay A, Morgan FD (2011) Hydrogeophysical methods for analyzing aquifer storage and recovery systems. Groundwater 49(2):250-269
Murat RC (1972) Stratigraphy and paleogeography of the cretaceous and lower tertiary in southern Nigeria. In: Dessauvagie TFJ, Whiteman AJ (eds) African geology. Ibadan Univ. Press, Ibadan, pp 251-266

Nguimbous-Kouoh JJ, Takougang EMT, Nouayou R, Tabod CT, Manguelle-Dicoum E (2012) Structural interpretation of the Mamfe sedimentary Basin of southwestern Cameroon along the Manyu River using audiomagnetotellurics survey. International Scholarly Research Network (ISRN) Geophysics, p 7

Odigi MI (2011) Diagenesis and reservoir quality of cretaceous sandstones of Nkporo formation (campanian) southeastern Benue trough, Nigeria. J Geol Min Res 3(10):265-280

Odigi MI, Amajor LC (2009) Geochemical characterization of cretaceous sandstones from the Southern Benue Trough, Nigeria. Chin J Geochem 28:44-54

Odoh BI (2010) Electro-hydraulic anisotropy of fractures in parts of Abakaliki, Ebonyi State, Nigeria-using ARS method. Int Arch Appl Sci Technol 1(1):10-19

Offodile ME (1975) A mineral survey of the cretaceous of the Benue Valley, Nigeria. J Cretac Res 1:101-124

Ogilvy RD, Meldrum PI, Kuras O, Wilkinson PB, Chambers JE (2008) Advances in geoelectric imaging technologies for the measurement and monitoring of complex earth systems and processes. In: Proceedings 33rd international geological congress, Oslo, Norway. August 10-14, 2008

Okereke CS, Esu EO, Edet AE (1998) Determination of potential groundwater sites using geological and geophysical techniques in the Cross River State, Southeastern Nigeria. J Afr Earth Sci 27(1):149-163

Orellana E, Moony AM (1966) Master curve and tables for vertical electrical sounding over layered structures. Interciencia, Escuela

Ozcep F, Yıldırım E, Tezel O, Asci M, Karabulut S (2010) Correlation between electrical resistivity and soil-water content based artificial intelligent techniques. Int $\mathrm{J}$ Phys Sci 5(1):047-056

Panagopoulos GP, Bathrellos GD, Skilodimou HD, Martsouka FA (2012) Mapping urban water demands using multi-criteria analysis and GIS. Water Resour Manage 26(5):1347-1363

Papadopoulou-Vrynioti K, Alexakis D, Bathrellos GD, Skilodimou HD, Vryniotis D, Vasiliades E, Gamvroula D (2013) Distribution of trace elements in stream sediments of Arta plain (western Hellas): the influence of geomorphological parameters. J Geochem Explor 134:17-26

Papadopoulou-Vrynioti K, Alexakis D, Bathrellos GD, Skilodimou HD, Vryniotis D, Vasiliades E (2014) Environmental research and evaluation of agricultural soil of the Arta plain, western Hellas. J Geochem Explor 136:84-92

Petters SW, Okereke CS, Nwajide CS (1987) Geology of the Mamfe rift, south eastern Nigeria. In: Matheis G, Schandelmerer H (eds) Current research in African Earth Sciences. Balkema, Rotterdam, pp 299-302

Petters SW (1989) A regional hydrogeological study of rural water supply options for planning and implementation of phase II rural water programme in Cross River State. Unpubl Tech Rep Submitt DFFRI. Cross River State, $97 \mathrm{p}$

Pimentel D, Houser J, Preiss E, White O, Fang H, Mesnick L, Barsky T, Tariche S, Schreck J, Alpert S (1997) Water resources: agriculture, the environment, and society source: an assessment of the status of water resources. Bioscience 47(2):97-106

Piper AM (1944) A graphical interpretation of water analysis. Trans Am Geophys Union 5:914-928

Prasanth SVS, Magesh S, Jitheshlal KV, Chandrasekar N, Gangadhar K (2012) Evaluation of groundwater quality and its suitability for drinking and agricultural use in the coastal stretch of Alappuzha District, Kerala, India. Appl Water Sci 2:165-175. doi:10.1007/s13201-012-0042-5 
Ragunath HM (1987) Groundwater, 2nd edn. Wiley Eastern Ltd., New Delhi

Raju NJ, Reddy TVK (1998) Fracture pattern and electrical resistivity studies for groundwater exploration. J Environ Geol 34(2-3): 175-182

Raju N J (2007) Hydrogeochemical parameters for assessment of groundwater quality in the upper Gunjanaeru River basin, Cuddapah District, Andhra Pradesh, South India. Environ Geol 52(6): 1067-1074

Richards LA (1954) Diagnostics and improvement of saline and alkaline soils. US Dept. of Agriculture hand book no. 60. US Salinity Laboratory, Washington, DC

Sakthimurugan S (1995) Hydrogeological studies and simulation of contaminant migration in and round Dindigul, Anna district, Tamil Nadu. Ph.D Thesis (unpublished), M.S. University, Tirunelveli, p 214

Samsudin AR, Haryono A, Hamzah U, Rafek AG (2007) Salinity mapping of coastal groundwater aquifers using hydrogeochemical and geophysical methods: a case study from north Kelantan. Environ Geol, Malaysia. doi:10.1007/s00254-007-1124-9

Sawyer GN, McCartly DL (1967) Chemistry of sanitary engineers, 2nd edn. McGraw Hill, New York, p 518

Sawyer GN, McMcartly DL, Parkin GF (2003) Chemistry for environmental engineering and science, 5th edn. McGraw Hill, New York

Schroeder HA (1960) Relations between hardness of water and death rates from certain chronic and degenerative diseases in the United States. J Chron Dis 12:586-591

Soupios P, Kouli M, Vallianatos F, Vafidis A, Stavroulakis G (2007) Estimation of aquifer parameters from surficial geophysical methods. A case study of Keritis Basin in Crete. J Hydrol 338:122-131

Srinivasamoorthy K, Gopinath M, Chidambaram S, Vasanthavigar M, Sarma VS (2014) Hydrochemical characterization and quality appraisal of groundwater from Pungar sub basin, Tamilnadu, India. J of King Saud Univ Sci 26(1):37-52

Subba Rao N (2002) Geochemistry of groundwater in parts of Guntur district Andhra Pradesh, India. Environ Geol 41:552-562

Tijani MN (2004) Evolution of saline waters and brines in the BenueTrough, Nigeria. J Appl Geochem 19:1355-1365

Todd DK, Mays LW (2005) Groundwater hydrology, 3rd edn. Wiley, New York, p 636

Ukaegbu VU, Akpabio IO (2009) Geology and stratigraphy of middle cretaceous sequences Northeast of Afikpo Basin, Lower Benue Trough, Nigeria. Pac J Sci Technol 103:518-256

Vender Velpen BPA (1988) A computer processing package for D.C. Resistivity interpretation for an IBM compatibles, ITC JouR, Vol. 4, The Netherlands

Wallace JS (2000) Increasing agricultural water use efficiency to meet future food production. J Agric Ecosys Environ 82:105-119

WHO (2010) Drinking water standards, monitoring and reporting, vol 1 , recommendations, 2nd edn. WHO, Geneva, p 130

Wilcox LV (1948) The quality of water for irrigation uses. US Dept. Agri. Tech. Bull. 962. USDA, Washington, DC

Wilcox LV (1955) Classification and use of irrigation waters. USD Circular No. 969, p 19

Younger PL (2007) Groundwater in the environment: An introduction. Blackwell Publishing, Malden, p 318 